\title{
ECONOMIC INTEGRATION AND REDISTRIBUTIVE TAXATION: A SIMPLE MODEL WITH AMBIGUOUS RESULTS
}

\author{
ANDREAS HAUFLER \\ ALEXANDER KLEMM \\ GUTTORM SCHJELDERUP
}

CESIFO WORKING PAPER NO. 1853

CATEGORY 1: PubliC FinANCE

NOVEMBER 2006

An electronic version of the paper may be downloaded

- from the SSRN website:

- from the RePEc website:

www.SSRN.com

- from the CESifo website:

www.RePEc.org

www.CESifo-group.de 


\title{
ECONOMIC INTEGRATION AND REDISTRIBUTIVE TAXATION: A SIMPLE MODEL WITH AMBIGUOUS RESULTS
}

\begin{abstract}
The rise in foreign direct investment and the increasing activity of multinational firms expose national corporate tax bases to cross-country profit shifting, but also lead to rising profitability of the corporate sector. We incorporate these two effects of economic integration into a simple political economy model where the median voter decides on a redistributive income tax rate. In this setting economic integration may raise or lower the equilibrium tax rate, depending on whether the higher excess burden of the tax or the larger redistributive gains from the perspective of the representative worker are the dominant effect. Our simple model holds several implications for future empirical work on the relationship between globalization and the effective rate of capital taxation.
\end{abstract}

JEL Code: H20, F23.

Keywords: redistributive taxation, multinational firms, profit shifting.

$\begin{array}{cc}\text { Andreas Haufler } & \text { Alexander Klemm } \\ \text { Department of Economics } & \text { International Monetary Fund } \\ \text { University of Munich } & \text { Fiscal Affairs Department } \\ \text { Akademiestr. 1/II } & 70019^{\text {th }} \text { Street, } N . W . \\ \text { 80799 Munich } & \text { Washington DC 20431 } \\ \text { Germany } & \text { USA } \\ \text { Andreas.Haufler@Irz.uni-muenchen.de } & \text { aklemm@imf.org } \\ \text { Guttorm Schjelderup } \\ \text { Department of Economics } \\ \text { Norwegian School of Economics and Business Administration } \\ \text { Helleveien 30 } \\ \text { 5045 Bergen } \\ \text { Norway } \\ \text { Guttorm.Schjelderup@nh.no }\end{array}$

October 2006

We are indebted to Thiess Büttner, Peter Egger, Agnar Sandmo and Erling Steigum for valuable comments and suggestions. The usual disclaimer applies. The views expressed in this paper are those of the authors and should not be interpreted as the views of the institutions with which they are affiliated. 


\section{Introduction}

One of the most pronounced trends in the world economy over the last decades has been the rise in foreign direct investment and multinational activity. In the United States, for example, foreign profits made up around 5 per cent of all corporate profits earned by U.S. firms until the late $1960 \mathrm{~s}$, but this share has meanwhile risen to more than 25 per cent, and is probably even higher (Desai and Hines, 2004). As a consequence of this development national corporate tax bases have become more sensitive to tax changes. A particular tax-saving strategy of multinational firms is to shift profit from high-tax to low-tax countries in which they operate. Empirical evidence is accumulating that firms do indeed use this opportunity through various channels, such as transfer pricing, the allocation of overhead costs, and financial transactions within the multinational firm. ${ }^{1}$

There is, however, a second factor associated with economic integration and the rise of multinational firms. This relates to the empirical evidence showing that multinational firms are on average more productive than local firms (see e.g., Barba Navaretti and Venables, 2004). The difference in productivity (and profitability) has been explained by several factors. At the firm level, profitability may rise due to the ability to utilize differences in international factor prices (Helpman and Krugman, 1985). Productivity growth may also occur at the industry level, however, when firms are heterogeneous and economic integration reallocates market shares from domestic to multinational firms (Melitz, 2003). Recent empirical evidence for the U.S. manufacturing industry shows that economic integration leads to productivity growth both at the firm and at the industry level (Bernard et al., 2006). Similar evidence is obtained for the United Kingdom, where the shift towards the service sector, and in particular towards the highly profitable banking, finance and insurance branches is one of the factors explaining the rise in corporate tax revenues over the last two decades (Devereux et al., 2004).

The traditional literature on international tax competition has usually confined its attention to the increasing mobility of the capital tax base, while taking the distribution of gross-of-tax factor earnings as given. Therefore, the typical result in tax competition models is that increasing capital mobility leads governments to undercut each other's capital income tax rates, resulting in underprovision of public goods as well as relatively higher taxes on immobile factors (see Wilson, 1999 for a survey). Empirical evidence in

\footnotetext{
${ }^{1}$ A large number of studies provide evidence for profit shifting by U.S. multinationals; see Hines (1999) for a survey of the early literature. An early case study from Germany is Weichenrieder (1996). More recently, systematic evidence for profit shifting has also been found for European multinationals (Huizinga and Laeven, 2005). For an up-to-date survey of the empirical literature on firm location and profit shifting, see Devereux (2006).
} 
support of this theoretical prediction, however, is mixed. Statutory corporate tax rates have been significantly reduced in most OECD countries since the 1980s, but tax bases have simultaneously been broadened. As a consequence, effective tax rates on profits have fallen by much less than statutory rates, and in several countries they have not fallen at all (see Devereux, Griffith and Klemm, 2002). ${ }^{2}$

Only recently a literature strand has emerged that studies tax competition in models of industry agglomeration where economic integration changes the level of rents earned by imperfectly competitive firms (Kind et al., 2000; Baldwin and Krugman, 2004; Borck and Pflüger, 2006). These models do not allow for multinational firms and cross-country profit-shifting, however, but only consider the location decision of single-jurisdictional firms. This leads to a rather rigid determination of optimal tax policy: the core region always taxes away the excess of profits that firms can earn in its territory, vis-a-vis the other (periphery) country. As the model implies that these agglomeration rents will first rise and then fall as economic integration proceeds, so will optimal corporate tax rates. Moreover, analyzing tax competition in models of the "new economic geography" is a rather complex undertaking and solving the full tax game requires the use of numerical simulation methods, at least in the realistic case of partial firm agglomeration (Borck and Pflüger, 2006). ${ }^{3}$

The present short paper pursues a different approach to analyze the effects of economic integration on optimal redistributive taxation. We set up a highly stylized model that incorporates, in the simplest possible way, independent effects of economic integration on the profitability of multinational firms and on the ease with which these firms can shift profits to low-tax countries. These twin effects of economic integration are embedded into a simple political economy model with an internationally mobile profit tax base. Our stylized model allows us to derive a reduced-form expression for the optimal redistributive tax rate in the political-economic equilibrium. In this framework globalization increases both the redistributive gains, but also the efficiency costs of taxation from the perspective of the median voter. Hence economic integration has a fundamen-

\footnotetext{
${ }^{2}$ Several econometric analyses exist on this subject. These studies provide some evidence of a negative relationship between (different measures of) economic integration and the level of corporate taxation if the latter is measured by statutory or effective average tax rates. This relationship, however, is generally not robust to the precise specification used in the empirical model and it disappears completely when tax revenue is used as the dependent variable. See Rodrik (1997), Bretschger and Hettich (2002), Swank and Steinmo (2002), Slemrod (2004) and Winner (2005).

${ }^{3} \mathrm{~A}$ different extension of the standard tax competition model is analyzed by Fuest (2005). In his model economic integration increases the mobility of the capital tax base, but also raises the share of foreign firm ownership and thus strengthens the incentive to tax the profits accruing to foreigners. In Fuest's model, however, this last effect can only dominate the role of increased tax base mobility if governments can also use import tariffs.
} 
tally ambiguous effect on the redistributive tax rate in the political economy equilibrium. Finally, we characterize parameter constellations that lead to an increase or a decrease in the rate of capital taxation.

\section{The model}

We consider a model of two countries which are linked through both goods and capital flows. The home country, on which the analysis is focused, is populated by two types of individuals, capitalists (index $C$ ) and workers (index $L$ ). The total population is normalized to unity. There are $\mu$ workers and $(1-\mu)$ capitalists. Workers form the majority of the population so that $1>\mu>0.5$. There is one aggregate consumption good whose price is normalized to one. It takes one unit of domestic labour to produce one unit of the numeraire good; competitive market conditions then determine that the domestic wage rate is also one. Each worker exogenously supplies one unit of labour and receives a gross wage income of unity. Capitalists instead receive profit income $\pi$ from a multinational enterprise (MNE). Profits are zero if domestic workers are employed in production. However, positive profits can be earned by the multinational firm when it employs workers from the foreign country, which has a lower wage rate $W \leq 1 .{ }^{4}$ In a simple way this captures one of the most important motivations for foreign direct investment, namely to utilize lower factor prices abroad (Helpman and Krugman, 1985).

The home country levies a proportional, comprehensive income tax at rate $t$ on all wage and profit income. The labour tax base is internationally immobile, whereas the profit tax base is responsive to tax differentials between the home and foreign countries. Hence capitalists face two decisions in our model: they choose $(i)$ how much to produce abroad and (ii) how much profits to shift to the foreign country. Both of these decisions have been extensively discussed in the literature. We incorporate them here in a highly stylized way, in order to keep our argument as simple as possible.

We first turn to the decision on how much output the home-owned firm produces in the foreign country. While the labour input is cheaper, producing abroad adds extra transport costs for the firm. Transport costs are interpreted in a wide sense, including administrative hurdles and information costs. We model these costs as being convex in the volume of foreign production, reflecting, for example, increasing marginal monitoring costs when larger parts of production are outsourced. ${ }^{5}$ For simplicity we specify quadratic

\footnotetext{
${ }^{4}$ Such differences in unit labour costs could be due, for example, to the existence of trade unions in the home country.

${ }^{5}$ This is in line with some of the findings in the new theory of the multinational firm (see Marin and Verdier, 2003).
} 
transport costs of the form $\delta=X^{2} /(2 \alpha)$, where $X$ is the volume of foreign production and $1 / \alpha$ is a transport cost parameter. We interpret the inverse of the transport cost parameter, $\alpha$, as a measure of economic integration. Increasing economic integration (an increase in $\alpha$ ) will reduce the transaction costs for foreign direct investment, for example by reducing the communication costs within the MNE. With these specifications the firm's before-tax profits are given by

$$
\pi=X(1-W)-\frac{X^{2}}{2 \alpha}
$$

All profits are taxable in the home country. However, the capitalist is able to shift some of the profits abroad, either through transfer pricing or by using tax-efficient financing structures. ${ }^{6}$ Let $\beta$ be the share of profits that is transferred abroad in this way and denote the foreign tax rate by $T$. As in the case of the firm's production decisions it is costly to engage in profit shifting activities and the deadweight costs are convex in the share of profits transferred abroad. Hence, by analogy to the transportation costs incurred when the firm produces abroad, the real resources spent when transferring profits are $\varepsilon=\beta^{2} \pi /(2 \alpha)$. The after-tax income of the capitalist, $y^{C}$, is thus

$$
y^{C}=\pi\left[(1-\beta)(1-t)+\beta(1-T)-\frac{\beta^{2}}{2 \alpha}\right] \text {, }
$$

where $\pi$ is given in (1). Hence in our model the firm's output decision $(X)$ is separated from the decision on profit shifting. ${ }^{7}$

From (1) the capitalist maximizes profits by choosing

$$
X=\alpha(1-W) \equiv \alpha \Delta W
$$

where we have introduced $\Delta W$ as a short-hand notation for the exogenous international wage differential. From (3) the level of output produced abroad is a rising function of the unit wage differential and of the degree of economic integration.

Similarly, deriving the optimal level of $\beta$ from (2) and ruling out that the domestic firm declares more profits in the home country than it earns gives

$$
\beta=\max \{\alpha(t-T), 0\} .
$$

\footnotetext{
${ }^{6}$ Income can be shifted through borrowing and lending between the multinational's affiliates, because the interest paid on this internal loan is taxable in the lending country, but tax-deductible in the borrowing country. See Mintz and Smart (2004) for a detailed modelling of this tax avoidance mechanism.

${ }^{7}$ It should be emphasized that this simplification results from the specification of the transaction cost functions $\delta$ and $\varepsilon$. With more general specifications, the output and profit shifting decisions will interact. This interaction, however, significantly complicates the analysis without yielding qualitatively different results for the main issue under analysis. The separation of output and profit-shifting decisions is a common assumption in the literature; see Gresik (2001) for a survey.
} 
Hence the share of profits shifted abroad depends positively on the differential between the home and the foreign tax rates (if this differential is positive), and again on the integration measure $\alpha$.

Finally substituting (3) in (1) yields maximized gross profits

$$
\pi^{*}=\frac{\alpha}{2}(\Delta W)^{2}
$$

It follows from (4) and (5) that economic integration (a rise in $\alpha$ ) will raise the gross profits of the multinational firm, but at the same time increases the share of profits that is shifted abroad.

\section{Tax equilibrium and economic integration}

Tax policy in the home country is determined by the median voter. Given the assumptions on the distribution of the population, this individual is a representative worker who derives utility from the aggregate consumption good and a quasi-private public good. Both the private and the public good enter the workers's utility function linearly. ${ }^{8}$ Hence the representative worker's utility function is $u^{L}=(1-t)+\gamma r$, where $r$ is total (and per-capita) tax revenue collected. The constant marginal benefit of the public good is $\gamma<1$, implying that the worker suffers a utility loss when one unit of her private consumption is exchanged for one unit of the public good.

The proportional income tax falls on wage income and on the share of profit income that the capitalist reports in the home country. Using the optimal tax avoidance decision (4), total and per capita tax revenues are $r=t\{\mu+(1-\mu) \pi[1-\alpha(t-T)]\}$. Hence the utility of the representative worker in the home country is

$$
u^{L}=(1-t)+\gamma t\left\{\mu+(1-\mu) \pi^{*}[1-\alpha(t-T)]\right\}
$$

The equilibrium policy maximizes $u^{L}$ with respect to the proportional income tax $t$. This yields the home country's best response function

$$
t(T)=\frac{\gamma\left[\mu+(1-\mu) \pi^{*}(1+\alpha T)\right]-1}{2 \alpha \gamma(1-\mu) \pi^{*}}
$$

It is directly inferred from (7) that this function is upward-sloping.

Tax policy in the foreign country is modelled in the simplest possible way. We assume that the foreign country maximizes tax revenues from the profits of the multinational

\footnotetext{
${ }^{8} \mathrm{~A}$ well-defined optimal tax rate is obtained in our model, despite the linearity of the objective function in both arguments, because the excess burden of taxation is strictly convex in the tax rate.
} 
firm, which are given by $R=T \beta \pi^{*}=T \alpha(t-T) \pi^{*}$. The foreign country's best response function is then

$$
T=\frac{t}{2}
$$

which implies that the foreign country has the lower tax rate in the non-cooperative tax equilibrium.

Substituting (8) in (7) then determines the home country's income tax rate in the non-cooperative tax equilibrium

$$
t^{*}=\frac{2\left\{\gamma\left[\mu+(1-\mu) \pi^{*}\right]-1\right\}}{3 \alpha \gamma(1-\mu) \pi^{*}},
$$

where $\pi^{*}$ is given in (5). The equilibrium tax rate is rising in the preference parameter for public goods $(\gamma)$. It is positive, if the value of additional units of the public good that is financed by the tax contributions of the capitalist, $\gamma(1-\mu) \pi^{*}$, exceeds the utility loss for the worker from being taxed herself $(\gamma \mu-1<0)$. This is assumed in what follows. It can then be directly inferred from (9) that the home country's Nash equilibrium tax rate will rise, if the equilibrium level of gross profits $\left(\pi^{*}\right)$ is increased.

The core issue underlying our analysis is whether economic integration, as described by an increase in the parameter $\alpha$, leads to an increase or a reduction in the home country's equilibrium tax rate. From (8) this will also induce a foreign tax change of the same sign. From the reduced-form expression for $t^{*}$ in (9) and using (5), it is straightforward to derive

$$
\frac{d t^{*}}{d \alpha}=\underbrace{-\frac{\gamma\left[\mu+\left(1-\mu \pi^{*}\right]-1\right.}{3 \alpha^{2} \gamma(1-\mu) \pi}}_{(-)}+\underbrace{\frac{2(1-\gamma \mu)\left(d \pi^{*} / d \alpha\right)}{3 \alpha \gamma(1-\mu) \pi^{2}}}_{(+)}
$$

There are two counteracting effects in equation (10). The first term is unambiguously negative, if the equilibrium tax rate (9) is positive. This effect captures the increased efficiency costs of redistributive taxation when economic integration makes the domestic profit tax base more mobile internationally and increases profit-shifting to the low-tax country. The second effect is positive, however, as $1-\gamma \mu>0$ and $d \pi^{*} / d \alpha>0$ is implied by (5). This effect describes the additional redistributive gains from the income tax when economic integration raises the profits of the multinational firm. Depending on which of the two effects dominates, economic integration may thus either raise or lower the redistributive tax rate chosen by the median voter. ${ }^{9}$

\footnotetext{
${ }^{9}$ Note the difference between our results and those derived in political economy models of strategic delegation (Persson and Tabellini, 1992; Gottschalk and Peters, 2003). In these models the working majority is able to mitigate the downward pressure on capital tax rates by delegating decisions to
} 
To link the two counteracting effects in (10) to observable country characteristics we use the gross profit expression (5) and substitute the home and the foreign countries' equilibrium taxes from (8) and (9). The effects of economic integration can then alternatively be expressed as

$$
\frac{d t^{*}}{d \alpha}=\frac{-\left(T^{*}-2 t^{*}\right)}{2 \alpha}+\frac{(1-\mu \gamma)(\Delta W)^{2}}{3 \alpha \gamma(1-\mu) \pi^{2}}
$$

Hence the increased sensitivity of the tax base will be the dominant effect of economic integration, if the international tax differential is large and thus the motive for international profit shifting is strong. In contrast, if the international wage differential is large, then economic integration will lead to a substantial increase in the profits of multinational firms. From the perspective of the median voter, the redistributive gains from an income tax increase may then exceed the additional efficiency losses. Our results are summarized in the following proposition.

Proposition 1 Economic integration tends to increase (decrease) the redistributive income tax rate, if $(i)$ the equilibrium tax differential between the home and the foreign country is small (large); and (ii) the wage differential between the domestic and the foreign country is large (small).

\section{Conclusion}

This paper has started from two well-known effects that are associated with the rise in foreign direct investment and multinational firm activity. In contrast to nationally operating firms, MNEs have the opportunity to shift profits to low-tax countries, but they are also more profitable and thus raise the aggregate profitability in the corporate sector. Incorporating these facts into a simple political economy model we have shown that economic integration (a rise in the market share of multinational firms) increases the efficiency cost of capital taxation, but it also increases the redistributive benefits of the tax from the perspective of the median voter. As a consequence the relationship between the degree of economic integration and the redistributive income tax rate chosen by the representative worker is fundamentally ambiguous. This ambiguity is also the main justification for the modelling approach that we have followed. If a simple model like the one used here does not lead to a clear-cut relationship between economic integration and the level of redistributive taxation, then neither will a more complex one.

politicians that prefer a larger degree of redistribution than the median voter herself. Nevertheless, the only direct effect of economic integration is increased tax base mobility. As a consequence economic integration leads, in equilibrium, to an unambiguous decline in the level of redistributive taxation. 
Our finding may provide an explanation for the contrast between the clear theoretical prediction of falling tax rates that are derived in much of the literature on capital tax competition, and the rather mixed evidence found in empirical studies. In fact, existing studies may even overstate the negative relationship between globalization and the rate of capital taxation, because they typically focus only on taxes at the company level. If taxes at the shareholder level are also taken into account, this downward trend becomes even less clear in many countries. For example the German corporate tax reform of 2000 significantly reduced the federal corporate tax rate from 42 to 25 percent, but simultaneously ended the full crediting of the corporation tax against the personal income tax of German shareholders. Another case in point is Norway, which reduced the statutory corporate tax rate from 50.5 percent to 28 percent in 1992. The Norwegian tax reform of 2004 maintained this tax rate for undistributed company profits, but ended the zero taxation of dividends and subjected all dividend income exceeding a computed risk-free return on the investment to double taxation. The mandate that the Norwegian tax committee had was explicitly to narrow down the tax differential between capital taxes and wage taxes that had formed after the tax reform of 1992, and which had caused rising tensions in society from a redistributive point of view. ${ }^{10}$

In sum, despite large reductions in statutory corporate tax rates, the combined effects of the reforms in Germany and Norway implied that the effective tax burden on individual capital income - incorporating both the corporation tax and the individual income tax fell only slightly, if at all. To fully account for these developments, a more detailed model would have to be set up, where the government disposes of separate tax instruments at the company level and at the level of shareholders. However, our simple model is able to explain the small net effect on the overall effective capital tax rate as the result of two counteracting forces caused by economic integration.

Our analysis holds several testable implications for future work on the empirical relationship between economic integration and the effective rate of capital taxation. First, it implies that corporate tax revenue (as a percentage of GDP) is not a suitable measure for the effective tax rate, as this measure includes the effects of rising firm profitability. This conforms with the empirical results of Slemrod (2004) and earlier studies discussed in Bretschger and Hettich (2002) and Swank and Steinmo (2002), who do not find any negative, and in some cases they even find a positive relationship between economic integration and corporate tax revenue. Second, from the discussion above, a broader measure for the effective rate of capital taxation would be desirable that includes

\footnotetext{
${ }^{10} \mathrm{~A}$ detailed explanation for the mandate and the reform can be found at http://odin.dep.no/fin/english/topics/p4500279/reform/006071-230126/dok-bn.html
} 
taxes levied at the shareholder level. Such a measure would be able to capture offsetting tax changes at the company level and at the level of individual shareholders. Finally, to isolate the effect that economic integration has on the international mobility of the capital tax base, the level of pre-tax profitability of firms needs to be controlled for. Only then would we expect to find a robustly negative effect of economic integration on the effective rate of capital taxation. 


\section{References}

Baldwin, R.E. and P. Krugman (2004), Agglomeration, integration and tax harmonisation. European Economic Review 48, 1-23.

Barba Navaretti, G. and T. Venables (2004). Multinational Firms in the World Economy. Princeton University Press.

Bernard, A., B. Jensen and P. Schott (2006), Trade costs, firms and productivity. Journal of Monetary Economics 53, 917-937.

Borck, R. and M. Pflüger (2006), Agglomeration and tax competition. European Economic Review 50, 647-668.

Bretschger, L. and F. Hettich (2002), Globalisation, capital mobility and tax competition: Theory and evidence for OECD countries. European Journal of Political Economy 18, 695-716.

Desai, M.A. and J.R. Hines (2004), Old rules and new realities: Corporate tax policy in a global setting. National Tax Journal 57, 937-960.

Devereux, M. (2006), The impact of taxation on the location of capital, firms and profit: A survey of empirical evidence. Paper presented at the European Tax Policy Forum. Institute for Fiscal Studies, London, April 2006.

Devereux, M. P., R. Griffith, and A. Klemm (2002), Corporate income tax reforms and international tax competition. Economic Policy 35, 451-495.

Devereux, M. P., R. Griffith, and A. Klemm (2004), Why has the UK corporation tax raised so much revenue? Fiscal Studies 25, 367-388.

Fuest, C. (2005), Economic integration and tax policy with endogenous foreign firm ownership, Journal of Public Economics 89, 1823-1840.

Gottschalk, S. and W. Peters (2003), Redistributive taxation in the era of globalization. International Tax and Public Finance 10, 453-468.

Gresik, T. (2001), The taxing task of taxing transnationals. Journal of Economic Literature 39, 800-838.

Helpman, E. and P. Krugman (1985), Market structure and foreign trade. MIT Press, Cambridge. 
Hines. J.R., 1999, Lessons from behavioral responses to international taxation, National Tax Journal 52, 304-322

Huizinga, H. and L. Laeven (2005), International profit shifting within European multinationals. Mimeo, Tilburg University.

Kind, H.J. K.H. Midelfart Knarvik and G. Schjelderup, 2000, Competing for capital in a "lumpy" world, Journal of Public Economics 78, 253-274.

Marin, D. and T. Verdier (2003), Globalization and the 'New Enterprise'. Journal of the European Economic Association 1,337-344.

Melitz, M.J. (2003), The impact of trade on intra-industry reallocation and aggregate industry productivity. Econometrica 71, 1695-1725.

Mintz, J. and M. Smart (2004), Income shifting, investment, and tax competition: theory and evidence from provincial taxation in Canada. Journal of Public Economics 88, 1149-1168.

Persson, T. and G. Tabellini (1992), The politics of 1992: Fiscal policy and European integration. Review of Economic Studies 59, 689-701.

Rodrik, D. (1997), Has globalisation gone too far? Institute for International Economics, Washington, D.C.

Slemrod, J. (2004), Are corporate tax rates, or countries, converging? Journal of Public Economics 88, 1169-1186.

Swank, D. and S. Steinmo (2002), The new political economy of taxation in advanced capitalist democracies. American Journal of Political Science 46, 642-655.

Weichenrieder, A. (1996) Fighting international tax avoidance: The case of Germany. Fiscal Studies 17(1), 37-58

Wilson, J.D. (1999), Theories of tax competition. National Tax Journal 52, 269-304.

Winner, H. (2005), Has tax competition emerged in OECD countries? Evidence from panel data. International Tax and Public Finance 12, 667-687. 


\title{
CESifo Working Paper Series
}

\author{
(for full list see www.cesifo-group.de)
}

1792 Bertil Holmlund, Qian Liu and Oskar Nordström Skans, Mind the Gap? Estimating the Effects of Postponing Higher Education, August 2006

1793 Peter Birch Sørensen, Can Capital Income Taxes Survive? And Should They?, August 2006

1794 Michael Kosfeld, Akira Okada and Arno Riedl, Institution Formation in Public Goods Games, September 2006

1795 Marcel Gérard, Reforming the Taxation of Multijurisdictional Enterprises in Europe, a Tentative Appraisal, September 2006

1796 Louis Eeckhoudt, Béatrice Rey and Harris Schlesinger, A Good Sign for Multivariate Risk Taking, September 2006

1797 Dominique M. Gross and Nicolas Schmitt, Why do Low- and High-Skill Workers Migrate? Flow Evidence from France, September 2006

1798 Dan Bernhardt, Stefan Krasa and Mattias Polborn, Political Polarization and the Electoral Effects of Media Bias, September 2006

1799 Pierre Pestieau and Motohiro Sato, Estate Taxation with Both Accidental and Planned Bequests, September 2006

1800 Øystein Foros and Hans Jarle Kind, Do Slotting Allowances Harm Retail Competition?, September 2006

1801 Tobias Lindhe and Jan Södersten, The Equity Trap, the Cost of Capital and the Firm's Growth Path, September 2006

1802 Wolfgang Buchholz, Richard Cornes and Wolfgang Peters, Existence, Uniqueness and Some Comparative Statics for Ratio- and Lindahl Equilibria: New Wine in Old Bottles, September 2006

1803 Jan Schnellenbach, Lars P. Feld and Christoph Schaltegger, The Impact of Referendums on the Centralisation of Public Goods Provision: A Political Economy Approach, September 2006

1804 David-Jan Jansen and Jakob de Haan, Does ECB Communication Help in Predicting its Interest Rate Decisions?, September 2006

1805 Jerome L. Stein, United States Current Account Deficits: A Stochastic Optimal Control Analysis, September 2006 
1806 Friedrich Schneider, Shadow Economies and Corruption all over the World: What do we really Know?, September 2006

1807 Joerg Lingens and Klaus Waelde, Pareto-Improving Unemployment Policies, September 2006

1808 Axel Dreher, Jan-Egbert Sturm and James Raymond Vreeland, Does Membership on the UN Security Council Influence IMF Decisions? Evidence from Panel Data, September 2006

1809 Prabir De, Regional Trade in Northeast Asia: Why do Trade Costs Matter?, September 2006

1810 Antonis Adam and Thomas Moutos, A Politico-Economic Analysis of Minimum Wages and Wage Subsidies, September 2006

1811 Guglielmo Maria Caporale and Christoph Hanck, Cointegration Tests of PPP: Do they also Exhibit Erratic Behaviour?, September 2006

1812 Robert S. Chirinko and Hisham Foad, Noise vs. News in Equity Returns, September 2006

1813 Oliver Huelsewig, Eric Mayer and Timo Wollmershaeuser, Bank Behavior and the Cost Channel of Monetary Transmission, September 2006

1814 Michael S. Michael, Are Migration Policies that Induce Skilled (Unskilled) Migration Beneficial (Harmful) for the Host Country?, September 2006

1815 Eytan Sheshinski, Optimum Commodity Taxation in Pooling Equilibria, October 2006

1816 Gottfried Haber and Reinhard Neck, Sustainability of Austrian Public Debt: A Political Economy Perspective, October 2006

1817 Thiess Buettner, Michael Overesch, Ulrich Schreiber and Georg Wamser, The Impact of Thin-Capitalization Rules on Multinationals' Financing and Investment Decisions, October 2006

1818 Eric O’N. Fisher and Sharon L. May, Relativity in Trade Theory: Towards a Solution to the Mystery of Missing Trade, October 2006

1819 Junichi Minagawa and Thorsten Upmann, Labor Supply and the Demand for Child Care: An Intertemporal Approach, October 2006

1820 Jan K. Brueckner and Raquel Girvin, Airport Noise Regulation, Airline Service Quality, and Social Welfare, October 2006

1821 Sijbren Cnossen, Alcohol Taxation and Regulation in the European Union, October 2006 
1822 Frederick van der Ploeg, Sustainable Social Spending in a Greying Economy with Stagnant Public Services: Baumol’s Cost Disease Revisited, October 2006

1823 Steven Brakman, Harry Garretsen and Charles van Marrewijk, Cross-Border Mergers \& Acquisitions: The Facts as a Guide for International Economics, October 2006

1824 J. Atsu Amegashie, A Psychological Game with Interdependent Preference Types, October 2006

1825 Kurt R. Brekke, Ingrid Koenigbauer and Odd Rune Straume, Reference Pricing of Pharmaceuticals, October 2006

1826 Sean Holly, M. Hashem Pesaran and Takashi Yamagata, A Spatio-Temporal Model of House Prices in the US, October 2006

1827 Margarita Katsimi and Thomas Moutos, Inequality and the US Import Demand Function, October 2006

1828 Eytan Sheshinski, Longevity and Aggregate Savings, October 2006

1829 Momi Dahan and Udi Nisan, Low Take-up Rates: The Role of Information, October 2006

1830 Dieter Urban, Multilateral Investment Agreement in a Political Equilibrium, October 2006

1831 Jan Bouckaert and Hans Degryse, Opt In Versus Opt Out: A Free-Entry Analysis of Privacy Policies, October 2006

1832 Wolfram F. Richter, Taxing Human Capital Efficiently: The Double Dividend of Taxing Non-qualified Labour more Heavily than Qualified Labour, October 2006

1833 Alberto Chong and Mark Gradstein, Who's Afraid of Foreign Aid? The Donors' Perspective, October 2006

1834 Dirk Schindler, Optimal Income Taxation with a Risky Asset - The Triple Income Tax, October 2006

1835 Andy Snell and Jonathan P. Thomas, Labour Contracts, Equal Treatment and WageUnemployment Dynamics, October 2006

1836 Peter Backé and Cezary Wójcik, Catching-up and Credit Booms in Central and Eastern European EU Member States and Acceding Countries: An Interpretation within the New Neoclassical Synthesis Framework, October 2006

1837 Lars P. Feld, Justina A.V. Fischer and Gebhard Kirchgaessner, The Effect of Direct Democracy on Income Redistribution: Evidence for Switzerland, October 2006

1838 Michael Rauscher, Voluntary Emission Reductions, Social Rewards, and Environmental Policy, November 2006 
1839 Vincent Vicard, Trade, Conflicts, and Political Integration: the Regional Interplays, November 2006

1840 Erkki Koskela and Mikko Puhakka, Stability and Dynamics in an Overlapping Generations Economy under Flexible Wage Negotiation and Capital Accumulation, November 2006

1841 Thiess Buettner, Michael Overesch, Ulrich Schreiber and Georg Wamser, Taxation and Capital Structure Choice - Evidence from a Panel of German Multinationals, November 2006

1842 Guglielmo Maria Caporale and Alexandros Kontonikas, The Euro and Inflation Uncertainty in the European Monetary Union, November 2006

1843 Jan K. Brueckner and Ann G. Largey, Social Interaction and Urban Sprawl, November 2006

1844 Eytan Sheshinski, Differentiated Annuities in a Pooling Equilibrium, November 2006

1845 Marc Suhrcke and Dieter Urban, Are Cardiovascular Diseases Bad for Economic Growth?, November 2006

1846 Sam Bucovetsky and Andreas Haufler, Preferential Tax Regimes with Asymmetric Countries, November 2006

1847 Luca Anderlini, Leonardo Felli and Andrew Postlewaite, Should Courts always Enforce what Contracting Parties Write?, November 2006

1848 Katharina Sailer, Searching the eBay Marketplace, November 2006

1849 Paul De Grauwe and Pablo Rovira Kaltwasser, A Behavioral Finance Model of the Exchange Rate with Many Forecasting Rules, November 2006

1850 Doina Maria Radulescu and Michael Stimmelmayr, ACE vs. CBIT: Which is Better for Investment and Welfare?, November 2006

1851 Guglielmo Maria Caporale and Mario Cerrato, Black Market and Official Exchange Rates: Long-Run Equilibrium and Short-Run Dynamics, November 2006

1852 Luca Anderlini, Leonardo Felli and Andrew Postlewaite, Active Courts and Menu Contracts, November 2006

1853 Andreas Haufler, Alexander Klemm and Guttorm Schjelderup, Economic Integration and Redistributive Taxation: A Simple Model with Ambiguous Results, November 2006 